\title{
MODEL PEMBERDAYAAN PETANI MENUJU KETAHANAN PANGAN KELUARGA
}

\author{
(Model of Farmer Empowerment for Household Food Security)
}

\author{
Ikeu Tanziha ${ }^{1 *}$
}

1 Departemen Gizi Masyarakat, Fakultas Ekologi Manusia, Institut Pertanian Bogor, Bogor 16680.

* Alamat korespondensi: Departemen Gizi Masyarakat, Fakultas Ekologi Manusia, Institut Pertanian Bogor, Bogor 16680. Telp: 0251-8621258, Fax: 0251-8622276, Email: ikeutanziha@yahoo.com

\begin{abstract}
The purpose of this study was to analyze the model of farmer empowerment for household food security. Research design was cross sectional, it was conducted in Lebak District on March- November 2010. The data collected was household characteristics, consumption, level of farmer empowerment, and household food security. A systematic stratified random sampling was applied to select 95 farmer households. The path analysis was applied to analyze Model of Farmer Empowerment for Household Food Security. The results showed that $42.1 \%$ of farmer household are food insecure, and most of them (52.6\%) have low level of empowerment. Model of farmer empowerment for food security can be started with the development and strengthening of megapolitan environment, followed by strengthening the means of production and capital.
\end{abstract}

Key words: Food security, Farmer, empowerment

\section{PENDAHULUAN}

Kemiskinan masih merupakan masalah besar di dunia terutama di negara-negara berkembang. di Indonesia sendiri, meskipun tingkat kemiskinan sudah menurun namun penurunan tersebut belum mencapai target RPJM. Kemiskinan di Indonesia lebih terpusat di daerah pedesaan yang identik dengan petani. Sumawinata (2004) menyebutkan bahwa lebih 80 persen rakyat Indonesia hidup di pedesaan, dimana hanya sekitar 10-15 persen yang merupakan golongan menengahatas. Bahkan dari sekitar 80 persen sisanya merupakan rakyat desa serba kekurangan, 40 persennya tergolong rakyat desa sangat miskin dan miskin, serta proporsi terbesar penduduk miskin adalah penduduk yang sumber penghasilannya dari pertanian (petani).

Persoalan menjadi lebih pelik karena jumlah petani gurem dengan lahan tidak sampai 0.5 hektar semakin lama semakin meningkat. Hasil Sensus Pertanian 2003 menunjukkan bahwa jumlah rumah tangga pertanian meningkat menjadi 25.4 juta dari sekitar 20.8 juta pada tahun 1993 atau meningkat sebesar 2.2 persen per tahun. Jumlah petani gurem pun ikut meningkat dari 10.8 juta $(52.7 \%)$ menjadi 13.7 juta (56.5 \%) rumah tangga.

Kemiskinan meningkatkan peluang rumahtangga pada kejadian rawan pangan, dimana kejadian rawan pangan khususnya pada rumahtangga petani diprediksi akan bertambah dengan adanya perubahan iklim (global warming). Global warming berdampak pada perubahan pola distribusi ketersediaan air secara spatial dan temporal, dan menyebabkan peluang kekeringan di musim kemarau meningkat dan peluang banjir di musim hujan akan meningkat pula. Kondisi ini menyebabkan terganggunya sistem produksi pangan seperti awal tanam mundur, intensitas tanam berkurang, intensitas organisme pengganggu tanaman akan meningkat, dan yang lebih parah adalah gagal panen karena terendamnya sawah akibat kebanjiran. Data dampak banjir pada musim hujan 2007/2008 terhadap produksi pangan utama menunjukkan bahwa 165915 ha sawah terkena banjir dan 67855 ha sawah terserang penyakit puso (Nainggolan, 2008).

Berdasarkan uraian diatas, dirasa perlu meningkatkan keberdayaan rumahtangga petani unuk dapat mempertahankan bahkan meningkatkan kemampuannya dalam mencapai kondisi rumahtangga tahan pangan.

Tujuan

\section{Tujuan Umum}

Menganalisis model pemberdayaan petani menuju ketahanan pangan. 


\section{Tujuan Khusus}

1. Menganalisis ketahanan pangan keluarga petani

2. Menganalisis tingkat keberdayaan petani

3. Menganalisis faktor-faktor yang berhubungan dengan pemberdayaan petani

4. Merumuskan model pemberdayaan petani menuju ketahanan pangan

\section{METODE}

\section{Desain, Waktu dan Lokasi}

Penelitian ini mengintegrasikan pendekatan atau metode kuantitatif dan kualitatif. Kombinasi kedua metode ini diharapkan dapat memperkaya data dan memahami fenomena sosial yang sedang diteliti. Disain penelitian adalah cros sectional. Penelitian dilakukan di Desa Pasindangan, Kecamatan Cileles dan di Desa Banjarsari Kecamatan Warunggunung, Kabupaten Lebak, provinsi Banten dari bulan April sampai dengan bulan Oktober 2008. Penentuan lokasi penelitian dilakukan secara purposive yaitu wilayah tipologi desa tipe 3 dan tipe 2 yaitu berturut-turut wilayah yang mempunyai tingkat kesejahteraan rendah yang memiliki potensi utama pertanian dan tingkat kesejahteraan tinggi yang memiliki potensi utama pertanian di wilayah Kabupaten Lebak Banten.

\section{Teknik Pengambilan Contoh}

Populasi penelitian adalah keluarga petani yang digolongkan berdasarkan penggolongan rumahtangga BPS, yaitu: buruh tani, petani gurem $(<0.5 \mathrm{ha})$, pengusaha pertanian (0.5-1 ha), pengusaha pertanian $(>1$ ha) dan tinggal di Desa Pasindangan dan Desa Banjarsari. Contoh diambil secara purposif sebanyak masing-masing 50 keluarga per desa, sehingga total sampel 100 keluarga.

\section{Sumber dan Teknik Pengambilan Data}

Prosedur pengumpulan data dan strategi yang digunakan dalam melakukan penelitian ini meliputi tahapan-tahapan seperti yang tercantum pada Tabel 1 .

\section{Pengolahan dan Analisa Data}

Data yang terkumpul dianalisis dengan menggunakan metode analisis data kualitatif dan kuantitatif. Secara umum analisis data kualitatif yang digunakan adalah analisis keberdayaan petani dan faktor-faktor
Tabel 1. Sumber dan Teknik Pengumpulan Data

\begin{tabular}{|c|c|c|}
\hline No. & $\begin{array}{l}\text { Jenis data yang } \\
\text { dikumpulkan }\end{array}$ & $\begin{array}{c}\text { Sumber data dan teknik } \\
\text { pengumpulan data }\end{array}$ \\
\hline \multicolumn{3}{|c|}{ Data kualitatif : } \\
\hline 1. & $\begin{array}{l}\text { - Karakteristik dan } \\
\text { dinamika sosial, } \\
\text { budaya dan ekonomi } \\
\text { masyarakat } \\
\text {-Kelembagaan lokal }\end{array}$ & $\begin{array}{l}\text { Data sekunder yang } \\
\text { diperoleh dari laporan- } \\
\text { laporan serta data primer } \\
\text { yang diperoleh melalui } \\
\text { focus group discussion }\end{array}$ \\
\hline \multicolumn{3}{|c|}{ Data kuantitatif : } \\
\hline 2. & $\begin{array}{l}\text {-Potensi pangan } \\
\text { wilayah (produksi, } \\
\text { ketersediaan pang- } \\
\text { an, ketersediaan } \\
\text { lahan, tingkat } \\
\text { kesuburan lahan) }\end{array}$ & $\begin{array}{lrr}\text { Diperoleh } & \text { dari } & \text { data } \\
\text { sekunder } & \text { (laporan- } \\
\text { laporan) } & \end{array}$ \\
\hline 3. & $\begin{array}{l}\text {-Data konsumsi } \\
\text { pangan rumah } \\
\text { tangga petani } \\
\text { (jumlah dan jenis } \\
\text { pangan, kebiasaan } \\
\text { makan, frekuensi \& } \\
\text { sumber pangan) }\end{array}$ & $\begin{array}{l}\text { Diperoleh melalui Recall } \\
2 \times 24 \text { jam dan semi } \\
\text { quantiatif food frequensi }\end{array}$ \\
\hline 4. & $\begin{array}{l}\text { - Sosial ekonomi } \\
\text { rumahtangga petani } \\
\text { (umur, pendidikan, } \\
\text { pendapatan, jumlah } \\
\text { anggota rumah tang- } \\
\text { ga, akses terhadap } \\
\text { pangan, alokasi tena- } \\
\text { ga kerja dan pengam. } \\
\text { bil keputusan) }\end{array}$ & wawancara \\
\hline
\end{tabular}

yang mempengaruhinya. Analisis data Sumber dan Teknik Pengumpulan Data kualitatif dilakukan melalui proses penyaringan data, penggolongan/ pengakategorian, penyimpulan serta uji ulang. Dalam proses analisis data kualitatif, setiap interpretasi logis atas data, akan dilengkapi dengan data-data kuantitatif sepanjang data tersebut dapat mendukung, mempertajam dan memperjelas interpretasi.

Analisis data kuantitaif dilakukan secara deskriptif melalui tabulasi silang, yaitu konsumsi, ketahanan pangan keluarga dan path analisis. Ketahanan pangan dan kuantitatif dihitung dengan dua cara yaitu 1 ) hanya berdasarkan tingkat kecukupan energi yaitu dikategorikan tahan pangan bila ratarata tingkat kecukupan energinya perhari $\geq$ 70\% kecukupan, dan dikategorikan rawan pangan apabila konsumsi energinya perhari < $70 \%$ kecukupan. Pengkategorian keberdayaan dimulai dengan pemberian skor pada setiap pertanyaan dalam kuesioner dan pengkategorian dilakukan berdasarkan rata-rata \pm sd. Model pemberdayaan petani menuju ketahanan pangan dilakukan dengan menganalisis pengaruh langsung dan tidak langsung menggunakan analisis jalur. Menurut Yamin dan Kurniawan (2009), dalam analisis jalur terdapat pengaruh tidak langsung. Besarnya pengaruh tidak langsung suatu variabel 
terhadap variabel tertentu dapat dihitung dengan cara mengalikan koefisienkoefisien regresi (beta- $B$ ) dari variabel pemberi efek.

Analisis model penguatan modal komunitas petani dalam upaya pencegahan dan penanggulangan kelaparan

Analisis model penguatan modal komunitas pertanian dari data kualitatif yang dikuantitatifkan melalui pemberian skor dari setiap jawaban yang dikumpulkan dianalisis dengan analisis jalur (Path analysis). Analisis jalur merupakan pengembangan dari analisis korelasi yang dibangun dari diagram jalur yang dihipotesiskan oleh peneliti dalam menjelaskan mekanisme hubungan kausal antar variabel dengan cara menguraikan koefisien korelasi menjadi pengaruh langsung dan tidak langsung (Yamin \& Kurniawan, 2009).

Analisis jalur adalah Sebuah metode untuk mempelajari pengaruh langsung dan tidak langsung dari variable-variabel. Dikembangkan pertama kali oleh Wright (1921) dalam Kenny (1979). Analisis jalur dapat digunakan untuk menganalisis hubungan sebab akibat antara satu variabel dengan variabel lainnya. Prosedur ini dapat menduga koefisienkoefisien sejumlah persamaan struktural linear yang mewakili hubungan sebab akibat yang menjadi hipotesis (Kenny, 1979). Adapun model analisis jalur yang akan diuji pada penelitian ini dapat dilihat pada Gambar 1.

\section{HASIL DAN PEMBAHASAN}

Karakteristik Sosial Ekonomi Rumah Tangga Contoh

Umur

Umur kepala rumah tangga berkisar antara 26 sampai 85 tahun, dan rataan $46.44 \pm$ 11.87. Baik di Desa di Desa Pasindangan maupun di Desa Banjarsari proporsi terbesar kepala rumah tangga berada pada kelompok umur dewasa madya (40-59 tahun) yaitu masing-masing $74 \%$ dan $41.2 \%$. Demikian pula dengan ibu, proporsi terbesar kepala rumah tangga berada pada kelompok umur dewasa madya (40-59 tahun) yaitu masing-masing $46.0 \%$ dan $47.1 \%$

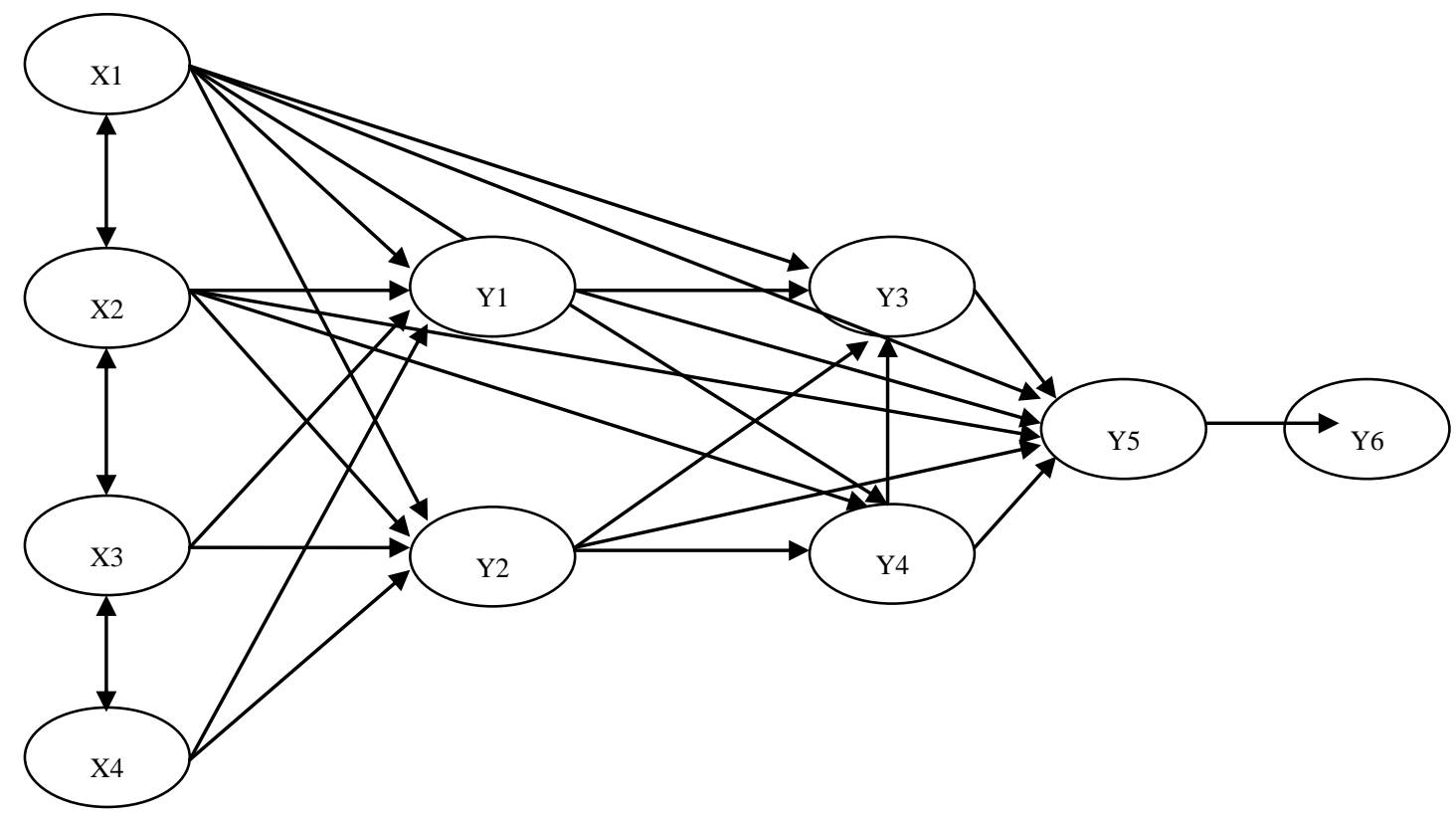

Keterangan:

$\mathrm{X} 1=$ Kondisi sosial ekonomi, $\mathrm{X} 2=$ Modal sosial, $\mathrm{X} 3=$ Lingkungan fisik, $\mathrm{X} 4=$ Lingkungan megapolitan, $\mathrm{Y} 1=$ Ketersediaan sarana dan prasarana, $\mathrm{Y} 2=$ Kemampuan akses informasi, $\mathrm{Y} 3=$ Teknologi, $\mathrm{Y} 4$ = Tingkat motivasi, $\mathrm{Y} 5=$ Keberdayaan, $\mathrm{Y} 6=$ Ketahanan Pangan.

Gambar 1. Model Pemberdayaan petani menuju ketahanan pangan keluarga 


\section{Pendidikan}

Lama pendidikan kepala rumah tangga di Desa Pasindangan maupun Banjarsari berkisar antara 0 hingga 12 tahun dengan rataan masing-masing $4.80 \pm 3.162$, dan rataan 4.37 \pm 3.404. Proporsi terbanyak KRT untuk kedua desa pada tingkat SD yaitu masingmasing $69.3 \%$ dan $71.7 \%$. Demikian pula proporsi terbanyak ibu rumahtangga untuk kedua desa pada tingkat SD yaitu masingmasing $66.0 \%$ dan $72.5 \%$. Berdasarkan uji beda, tidak ada perbedaan signifikan pendidikan di kedua desa.

\section{Pekerjaan}

Tidak semua petani mempunyai pekerjaan tambahan, diantaranya hanya $51.5 \%$ yang mempunyai pekerjaan tambahan. Terdapat perbedaan jenis pekerjaan tambahan yang banyak dilakukan di kedua desa, yaitu di Desa Pasindangan proporsi terbesar (32\%) sebagai pedagang, sedangkan di Banjarsari Proporsi terbesar (37.3\%) mempunyai pekerjaan tambahan sebagai buruh.

\section{Luas Lahan Garapan}

Luas lahan garapan contoh berkisar antara 0-20 $000 \mathrm{~m}^{2}$ dengan rataan $3943.76 \pm$ $4539.422 \mathrm{~m}^{2}$. Di Desa Pasindangan rataan luas lahan garapan lebih besar dibanding di Banjarsari yaitu masing-masing sebesar 5072.0 $\pm 4519.574 \mathrm{~m}^{2}$ dan 2837.65 $4321.320 \mathrm{~m}^{2}$. Proporsi terbesar $38 \%$ luas lahan garapan di desa Pasindangan berkisar antara 5 000-10 000 $\mathrm{m}^{2}$, sedangkan di Desa Banjarsari sebagian besar $(52.9 \%)$ contoh memiliki luas lahan kurang dari $5000 \mathrm{~m}^{2}$.

\section{Tingkat Ketahanan Pangan Keluarga Petani}

Tingkat kecukupan energi merupakan kondisi tercukupinya kebutuhan pangan seseorang agar dapat hidup sehat dan produktif (FAO). Pengukuran ketahanan pangan diantaranya diukur dengan tingkat kecukupan energi seseorang.

\section{Konsumsi Energi}

Konsumsi pangan dan gizi yang cukup serta seimbang merupakan faktor penting dalam menentukan tingkat kesehatan dan kecerdasan seseorang, sebab tingkat kecukupan gizi seseorang sangat mempengaruhi perkembangan jasmani dan rohani (Bimas Ketahanan Pangan 2001). Ratarata tingkat kecukupan zat gizi di Desa Pasindangan dan Desa Banjarsari bisa dilihat pada Tabel 2.
Tabel 2. Rata-rata Tingkat Kecukupan Zat Gizi di Desa Pasindangan dan Desa Banjarsari

\begin{tabular}{|c|c|c|c|}
\hline \multirow[b]{2}{*}{ Zat Gizi } & \multicolumn{2}{|c|}{ Desa } & \multirow{2}{*}{$\begin{array}{c}\text { Rata-rata } \\
\text { Desa-Kota } \\
(\%)\end{array}$} \\
\hline & $\begin{array}{c}\text { Pasindangan } \\
\text { (\%) }\end{array}$ & $\begin{array}{c}\text { Banjarsari } \\
\text { (\%) }\end{array}$ & \\
\hline Energi & 128.4 & 131.6 & 129.9 \\
\hline Protein & 106.6 & 118.9 & 112.4 \\
\hline Kalsium & 29.5 & 27.3 & 28.5 \\
\hline Zat Besi & 51.9 & 52.1 & 52.1 \\
\hline Vitamin A & 595.9 & 625.4 & 609.9 \\
\hline Vitamin C & 94.4 & 62.8 & 79.4 \\
\hline
\end{tabular}

Berdasarkan Tabel 2 dapat dilihat bahwa untuk konsumsi energi, protein, dan vitamin A di kedua desa (Pasindangan dan Banjarsari) sudah baik yaitu lebih dari 100.0\% AKG. Tingkat kecukupan zat gizi vitamin $C$ di Desa Pasindangan cenderung lebih baik bila dibandingkan dengan di Desa Banjarsari. Akan tetapi untuk zat gizi kalsium dan zat besi di kedua desa masih rendah, dimana tingkat kecukupan gizinya baru mencapai $28.5 \%$ untuk kalsium dan $52.1 \%$ untuk zat besi.

\section{Tingkat Ketahanan Pangan}

Ketahanan pangan diklasifikasikan berdasarkan tingkat kecukupan energi keluarga, yaitu dikategorikan tahan pangan apabila tingkat kecukupan energinya $\geq 90.0 \%$, dan dikategorikan rawan pangan jika tingkat kecukupan energinya < 90.0\% (FAO, 2003; Tanziha, 2006). Sebaran contoh berdasarkan tingkat ketahanan pangan dapat dilihat pada Tabel 3.

Tabel 3. Tingkat Ketahanan Pangan Keluarga Petani

\begin{tabular}{ccccccc}
\hline \multirow{2}{*}{$\begin{array}{c}\text { Tingkat } \\
\text { Ketahanan } \\
\text { Pangan }\end{array}$} & \multicolumn{2}{c}{$\begin{array}{c}\text { Pasinda- } \\
\text { ngan }\end{array}$} & \multicolumn{2}{c}{ Banjarsari } & \multicolumn{2}{c}{ Total } \\
\cline { 2 - 8 } & $\mathbf{n}$ & $\%$ & $\mathbf{n}$ & $\%$ & $\mathbf{n}$ & $\%$ \\
\hline $\begin{array}{l}\text { Rawan pangan } \\
\text { (TKE <90.0\%) }\end{array}$ & 20 & 40.0 & 20 & 44.4 & 40 & 42.1 \\
$\begin{array}{c}\text { Tahan pangan } \\
\text { (TKE } \geq 90.0 \%)\end{array}$ & 30 & 60.0 & 25 & 55.6 & 55 & 57.9 \\
\hline Total & 50 & 100.0 & 45 & 100.0 & 95 & 100.0 \\
\hline
\end{tabular}

Berdasarkan Tabel 3 diatas dapat dilihat bahwa lebih dari separuh contoh merupakan keluarga yang tahan pangan (57.9\%), sedangkan $42.1 \%$ lainnya merupakan keluarga yang tidak tahan pangan. Jumlah keluarga yang tahan pangan di Desa Pasindangan lebih banyak dibandingkan di Desa Banjarsari yaitu berturut-turut $60.0 \%$ dan $55.6 \%$.

\section{Tingkat Keberdayaan Keluarga Petani}

Pemberdayaan petani merupakan salah satu perwujudan dari pengembangan kapasitas 
masyarakat yang bernuansa pada peningkatan kualitas sumber daya manusia melalui penyediaan informasi pertanian dari tingkat pusat sampai tingkat perdesaan. Informasi yang diterima petani akan membuka wawasan berpikirnya dan dapat mengubah atau menyesuaikan konsep-konsep yang lama dalam diri petani tersebut menjadi konsep baru dengan sejumlah informas baru (Hubeis, 2000). Pada penelitian ini, indikator tingkat keberdayaan petani yang dilihat, adalah: kemampuan merencanakan, melaksanakan, mengevaluasi, dan mengatasi masalah usahatani (Tabel 4).

Tabel 4. Sebaran Petani Berdasarkan Komponen Keberdayaan

\begin{tabular}{lcccc}
\hline \multirow{2}{*}{$\begin{array}{c}\text { Komponen } \\
\text { Keberdayaan }\end{array}$} & \multicolumn{2}{c}{ Rendah } & \multicolumn{2}{c}{ Tinggi } \\
\cline { 2 - 5 } & $\mathrm{n}$ & $\%$ & $\mathrm{n}$ & $\%$ \\
\hline Merencanakan Usaha & 48 & 50.5 & 47 & 49.5 \\
Melaksanakan usaha & 54 & 56.4 & 41 & 43.6 \\
Mengevaluasi usaha & 47 & 49.5 & 48 & 50.5 \\
Mengatasi masalah & 66 & 69.3 & 29 & 30.7 \\
\hline
\end{tabular}

Dari Tabel 4 terlihat, sebagian besar petani berada dalam kemampuan yang rendah baik dalam merencanakan usaha (50.5\%), melaksanakan usaha (56.4), apalagi dalam mengatasi masalah usaha tani (69.3\%). Namun demikian sebagian besar petani (50.5\%) mampu dalam mengevaluasi usaha.

Bila keempat komponen ini dikompositkan menjadi kondsi keberdayaan petani, maka seperti terlihat dalam Tabel 5 , sebagian besar petani $(52.6 \%)$ berada dalam tingkat keberdayaan yang rendah.

Tabel 5. Tingkat Keberdayaan Petani

\begin{tabular}{ccccccc}
\hline \multirow{2}{*}{$\begin{array}{c}\text { Tingkat } \\
\text { Keberdayaan }\end{array}$} & \multicolumn{4}{c}{ Desa } & \multirow{2}{*}{ Total } \\
\cline { 2 - 6 } & \multicolumn{2}{c}{ Pasindangan } & \multicolumn{3}{c}{ Banjarsari } & \\
\cline { 2 - 6 } & $\mathbf{n}$ & $\%$ & $\mathbf{n}$ & $\%$ & $\mathbf{n}$ & $\%$ \\
\hline Rendah & 37 & 78.0 & 13 & 27.0 & 50 & 52.6 \\
Tinggi & 10 & 22.0 & 35 & 72.9 & 45 & 47.4 \\
\hline Total & 47 & 100 & 48 & 100 & 95 & 100 \\
\hline
\end{tabular}

Hal yang menarik adalah bila tingkat keberdayaan petani dilihat berdasarkan lokasi, maka terlihat bahwa petani di Desa Banjarsari yang merupakan desa kota, jauh lebih berdaya dibandingkan petani di Desa Pasindangan. Hal ini karena petani di Desa Banjarsari mempunyai akses yang lebih tinggi pada sumber informasi, dan sumber input pertanian.

\section{Faktor - Faktor yang Berhubungan dengan Keberdayaan Petani}

\section{Kondisi Sosial Ekonomi Petani}

Kondisi sosial ekonomi petani perlu diketahui untuk memahami hal-hal yang menyebabkan ketidakmampuan petani dalam pemenuhan kebutuhannya. Kondisi sosial ekonomi yang dianalisis adalah pendidikan, lama bekerja pada usaha tani, status penguasaan lahan dan pendapatan keluarga, yang kemudian dikompositkan menjadi tingkat sosial ekonomi (Tabel 6).

Tabel 6. Hubungan antara Kondisi Sosek Petani dan Tingkat Keberdayaan Petani

\begin{tabular}{|c|c|c|c|c|c|c|}
\hline \multirow{3}{*}{$\begin{array}{c}\text { Sosial } \\
\text { Ekonomi }\end{array}$} & \multicolumn{4}{|c|}{$\begin{array}{c}\text { Tingkat Keberdayaan } \\
\text { Petani }\end{array}$} & \multirow{2}{*}{\multicolumn{2}{|c|}{ Total }} \\
\hline & \multicolumn{2}{|c|}{ Rendah } & \multicolumn{2}{|c|}{ Tinggi } & & \\
\hline & $\mathrm{n}$ & $\%$ & $\mathrm{n}$ & $\%$ & $\mathrm{n}$ & $\%$ \\
\hline Rendah & 34 & 35.8 & 21 & 22.1 & 55 & 57.9 \\
\hline Tinggi & 16 & 16.8 & 24 & 25.3 & 40 & 42.1 \\
\hline Total & 50 & 52.6 & 45 & 47.4 & 95 & 100.0 \\
\hline
\end{tabular}

Dari Tabel 6 terlihat bahwa sebagian besar petani $(57.9 \%)$ dalam tingkat social ekonomi rendah, dan sebagian besar (68\%) dari keluarga petani tersebut berada pada tingkat keberdayaan yang rendah. Menurut Singh (2002) dalam Roosganda (2007) petani di Indonesia mayoritas merupakan petani kecil dengan penguasaan dan pengusahaan lahan yang relatif sempit $(<0.25 \mathrm{ha})$. Keterbatasan tersebut pada dasarnya bercirikan antara lain: (1) sangat terbatasnya penguasaan terhadap sumberdaya; (2) sangat menggantungkan hidupnya pada usahatani; (3) tingkat pendidikan yang relatif rendah; dan (4) secara ekonomi, mereka tergolong miskin. Hasil uji korelasi Pearson menunjukkan bahwa ada hubungan antara kondisi sosial ekonomi petani dengan tingkat keberdayaan petani $(p<0.05$, $r=0.357$ ).

\section{Kemampuan Akses Informasi}

Indikator pengukuran tingkat kemampuan petani dalam mengakses informasi pertanian dari berbagai sumber informasi, baik melalui kontak personal maupun melalui media massa meliputi: (1) kemampuan memperoleh informasi, (2) kemampuan memanfaatkan informasi, (3) kemampuan memilih informasi, (4) jumlah informasi baru yang diperoleh, (5) frekuensi memperoleh informasi dari kelompok tani, frekuensi kegiatan pelatihan atau penyuluhan yang diiukti, dan (6) kemampuan biaya memperoleh informasi. 
Tabel 7. Hubungan antara Kemampuan Akses Informasi dan Tingkat Keberdayaan Petani

\begin{tabular}{ccccccr}
\hline \multirow{2}{*}{$\begin{array}{c}\text { Kemampu } \\
\text { an Akses }\end{array}$} & \multicolumn{3}{c}{\begin{tabular}{c}
\multicolumn{2}{c}{ Tingkat Keberdayaan } \\
Petani
\end{tabular}} & \multirow{2}{*}{ Total } \\
\cline { 2 - 5 } Informasi & \multicolumn{2}{c}{ Rendah } & \multicolumn{2}{c}{ Tinggi } & & \\
\cline { 2 - 6 } & $\mathbf{n}$ & $\%$ & $\mathbf{n}$ & $\%$ & $\mathbf{n}$ & $\%$ \\
\hline Rendah & 23 & 24.2 & 25 & 26.3 & 48 & 50.5 \\
Tinggi & 27 & 28.4 & 20 & 21.1 & 47 & 49.5 \\
$\quad$ Total & 50 & 52.6 & 45 & 47.4 & 95 & 100.0 \\
\hline
\end{tabular}

Berdasarkan Tabel 7 dapat dilihat bahwa ternyata sebagian besar petani (55.6\%) yang kemampuan askes informasinya rendah justru memiliki tingkat keberdayaan yang tinggi. Aksesibilitas petani terhadap sumber informasi dipengaruhi oleh kemudahan petani mendapatkan informasi ditinjau dari aspek komunikatif, penggunaan saluran dan alat komunikasi, kegiatan penyuluhan dan keterjangkauan. Hasil uji korelasi Pearson menunjukkan bahwa tidak ada hubungan antara kemampuan akses informasi dengan tingkat keberdayaan petani $(p>0.05, r=0.008)$. $\mathrm{Hal}$ ini berbeda dengan hasil penelitian Hakim (2007) yang menunjukkan bahwa akses pada informasi berpengaruh positif keberdayaan petani, artinya akses pada informasi dapat dikembangkan dan dimanfaatkan untuk meningkatkan keberdayaan petani.

\section{Tingkat Motivasi Petani}

Motivasi adalah kegiatan memberikan dorongan kepada seseorang atau diri sendiri untuk mengambil suatu tindakan yang dikehendaki (Thoha, 2002). Adanya orientasi harapan sebagai fungsi motivasi akan memberikan dorongan kuat pada diri petani dalam pengembangan usaha tani. Tingkat motivasi petani dalam system usaha tani dapat dilihat pada Tabel 8.

Tabel 8. Hubungan antara Tingkat Kesadaran, Motivasi dan Keinovatifan dengan Tingkat Keberdayaan Petani

\begin{tabular}{lcccccc}
\hline \multirow{2}{*}{$\begin{array}{c}\text { Kesadaran, } \\
\text { Motivasi dan }\end{array}$} & \multicolumn{4}{c}{$\begin{array}{c}c \\
\text { Pingkat Keberdayaan }\end{array}$} & \multirow{2}{*}{ Total } \\
\cline { 2 - 5 } Keinovatifan & \multicolumn{2}{c}{ Rendah } & \multicolumn{2}{c}{ Tinggi } & & \\
\cline { 2 - 6 } & $\mathbf{n}$ & $\%$ & $\mathbf{n}$ & $\%$ & $\mathbf{n}$ & $\%$ \\
\hline Rendah & 12 & 24.0 & 6 & 13.3 & 18 & 18.9 \\
Tinggi & 38 & 76.0 & 39 & 86.7 & 77 & 81.1 \\
$\quad$ Total & 50 & 100.0 & 45 & 100.0 & 95 & 100.0 \\
\hline
\end{tabular}

Berdasarkan Tabel 8 terlihat bahwa sebagian besar $(81.1 \%)$ petani memiliki tingkat motivasi yang tinggi dalam usahatani. Hasil uji korelasi Pearson menunjukkan bahwa ada hubungan antara tingkat kesadaran, motivasi dan keinovatifan dengan tingkat keberdayaan petani $(\mathrm{p}<0.05, \mathrm{r}=0.231)$.

\section{Teknologi Peningkatan Produksi dan Pengolahan Hasil}

Teknologi bermanfaat bagi upaya peningkatan jumlah dan perbaikan mutu produksi; baik selama proses menghasilkan, pengolahan hasil, penyimpanan dan pengepakannya hingga produk tersebut diterima oleh konsumen.

Tabel 9. Hubungan antara Teknologi Peningkatan Produksi dan Mutu, serta Pengolahan Hasil dengan Tingkat Keberdayaan Petani Tingkat Keberdayaan

\begin{tabular}{|c|c|c|c|c|c|c|}
\hline \multirow{3}{*}{ Teknologi } & \multicolumn{4}{|c|}{$\begin{array}{c}\text { Tingkat Keberdayaan } \\
\text { Petani }\end{array}$} & \multirow{2}{*}{\multicolumn{2}{|c|}{ Total }} \\
\hline & \multicolumn{2}{|c|}{ Rendah } & \multicolumn{2}{|c|}{ Tinggi } & & \\
\hline & $\mathbf{n}$ & $\%$ & $\mathrm{n}$ & $\%$ & $\mathrm{n}$ & $\%$ \\
\hline Rendah & 32 & 64.0 & 15 & 33.3 & 47 & 49.5 \\
\hline Tinggi & 18 & 36.0 & 30 & 66.7 & 48 & 50.5 \\
\hline Total & 50 & 100.0 & 45 & 100.0 & 95 & 100.0 \\
\hline
\end{tabular}

Berdasarkan tabel 9dapat dilihat bahwa teknologi petani hampir setengahnya (49.5\%) masih dalam kategori rendah. Hasil uji korelasi Pearson menunjukkan bahwa ada hubungan antara teknologi peningkatan produksi dan mutu, serta pengolahan hasil dengan tingkat keberdayaan petani $(p<0.05$, $r=0.649$ ).

\section{Ketersediaan Sarana Produksi dan Permodalan}

Salah satu keterbatasan petani dalam mengembangkan usaha taninya adalah rendahnya permodalan, menurut Alimoeso (2008) dalam hal ini pemerintah harus memberikan fasilitas baik dalam bentuk hibah maupun kredit, karena tanpa fasilitasi pemerintah, sulit bagi usaha tani tersebut untuk meningkatkan efisiensi dan produktivitasnya.

Tabel 10. Hubungan antara Ketersediaan Sarana Produksi dan Permodalan dengan Tingkat Keberdayaan Petani

\begin{tabular}{ccccccc}
\hline \multirow{2}{*}{$\begin{array}{c}\text { Ketersedi } \\
\text { aan }\end{array}$} & \multicolumn{4}{c}{ Keberdayaan Petani } & \multirow{2}{*}{ Total } \\
\cline { 2 - 5 } & \multicolumn{2}{c}{ Rendah } & \multicolumn{2}{c}{ Tinggi } & & \\
\cline { 2 - 6 } & $\mathrm{n}$ & $\%$ & $\mathrm{n}$ & $\%$ & $\mathrm{n}$ & $\%$ \\
\hline Rendah & 0 & 0.0 & 0 & 0.0 & 0 & 0.0 \\
Tinggi & 50 & 100.0 & 45 & 100.0 & 95 & 100.0 \\
Total & 50 & 100.0 & 45 & 100.0 & 95 & 100.0 \\
\hline
\end{tabular}

Hasil uji korelasi Pearson menunjukkan bahwa ada hubungan antara ketersediaan sarana produksi dan permodalan dengan tingkat keberdayaan petani $(p<0.05, r=0.346)$. 


\section{Modal Sosial}

Bourdieu dalam Syahra et al. (2000) mendifinisikan modal sosial sebagai keseluruhan sumberdaya baik yang aktual maupun potensial yang dimiliki seseorang berkat adanya jaringan hubungan secara kelembagaan yang terpelihara dengan baik, yang mana setiap anggota dalam kelembagaan tersebut memperoleh keuntungan dari modal yang dimiliki secara kolektif.

Tabel 11. Hubungan antara Modal Sosial Dengan Tingkat Keberdayaan Petani

\begin{tabular}{ccccccc}
\hline \multirow{2}{*}{$\begin{array}{c}\text { Modal } \\
\text { Sosial }\end{array}$} & \multicolumn{4}{c}{$\begin{array}{c}\text { Tingkat Keberdayaan } \\
\text { Petani }\end{array}$} & \multirow{2}{*}{ Total } \\
\cline { 2 - 5 } & \multicolumn{2}{c}{ Rendah } & \multicolumn{2}{c}{ Tinggi } & & \\
\cline { 2 - 5 } & $\mathbf{n}$ & $\%$ & $\mathbf{n}$ & $\%$ & $\mathbf{n}$ & $\%$ \\
\hline Rendah & 31 & 32.6 & 23 & 24.2 & 54 & 56.8 \\
Tinggi & 19 & 20.0 & 22 & 23.2 & 41 & 43.2 \\
Total & 50 & 52.6 & 45 & 47.4 & 95 & 100.0 \\
\hline
\end{tabular}

Hasil uji korelasi Pearson menunjukkan bahwa ada hubungan antara lingkungan sosial dengan tingkat keberdayaan petani $(p>0.05$, $r=0.226$ ).

\section{Model Pemberdayaan Petani Menuju Ketahanan Pangan}

Pemberdayaan (empowerment) adalah serangkaian upaya dalam rangka memperluas akses masyarakat terhadap sumberdaya pembangunan melalui penciptaan peluang yang seluas-luasnya agar masyarakat lapisan bawah mampu berpartisipasi (Sumodiningrat, 1999). Model pemberdayaan yang diterapkan pada petani tidak mungkin berdiri sendiri, tetapi merupakan faktor-faktor yang saling berhubungan dan mempengaruhi satu sama lainnya. Model hubungan dan pengaruh antar variabel yang mempengaruhi tingkat keberdayaan petani dapat dilihat pada gambar 1, 2, dan 3.

\section{Model Pemberdayaan Petani Menuju Ketahanan Pangan di Pedesaan (Desa Pasindangan)}

Model pemberdayaan petani dianalisis berdasarkan karakteristik wilayah yaitu di wilayah desa pedesaan dan wilayah desa kota, hal ini dimaksudkan agar diperoleh hasil yang lebih sepesifik, sehingga intervensi lebih tepat. Model pemberdayaan petani di Desa Pasindangan (tipe pedesaan) dapat dilihat pada Gambar 2.

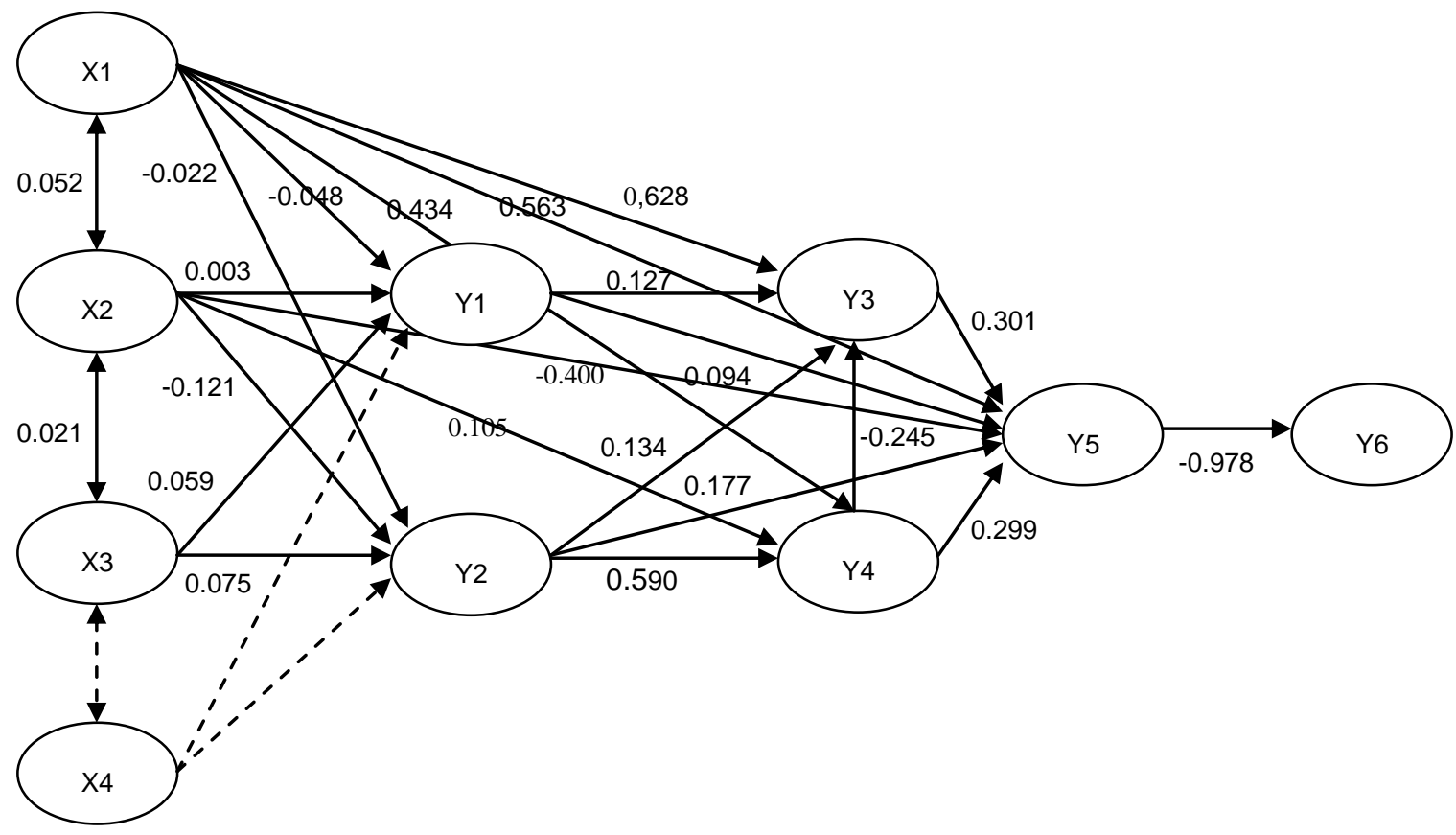

Keterangan:

$\mathrm{X} 1=$ Kondisi sosial ekonomi, $\mathrm{X} 2=$ Modal sosial, $\mathrm{X} 3=$ =ingkungan fisik, $\mathrm{X} 4=$ =Lingkungan megapolitan, $\mathrm{Y} 1=$ Ketersediaan sarana dan prasarana, $\mathrm{Y} 2$ = Kemampuan akses informasi, $\mathrm{Y} 3=$ Teknologi, Y4 = Tingkat motivasi, Y5 = Keberdayaan, Y6 = Ketahanan Pangan.

Gambar 2 Model Pemberdayaan petani menuju ketahanan pangan keluarga di daerah pedesaan 
Dari Gambar 2 terlihat bahwa variabel lingkungan sosial merupakan faktor determinan terhadap ketahanan pangan melalui tingkat keberdayaan petani dengan pengaruh total (total effect) sebesar $B=0.3912$ lebih tinggi bila dibandingkan dengan jalur lainnya. Dari berbagai jalur yang ada pada Gambar 2, ternyata untuk daerah pedesaan, uapaya peningkatan keberdayaan keluarga petani adalah dimulai dengan penguatan lingkungan sosial berupa penguatan norma masyarakat, interaksi dalam masyarakat, dukungan keluarga dan tokoh masyarakat. Artinya semakin kondusif lingkungan sosial maka keluarga petani pun akan semakin tahan pangan, seperti diutarakan oleh Roosganda (2007) bahwa faktor pendukung dalam upaya memberdayakan petani diantaranya adalah kekuatan solidaritas petani sebagai konsekuensi lahir dan terbentuk dari masyarakat di pedesaan.

\section{Model Pemberdayaan Petani di Perkotaan (Desa Banjarsari)}

Model pemberdayaan petani di daerah perkotaan berbeda dengan daerah Pedesaan. Pada daerah perkotaan kondisi megapolitan merupakan salah satu modal komunitas yang berpengaruh terhadap keberdayaan petani (Gambar 3).

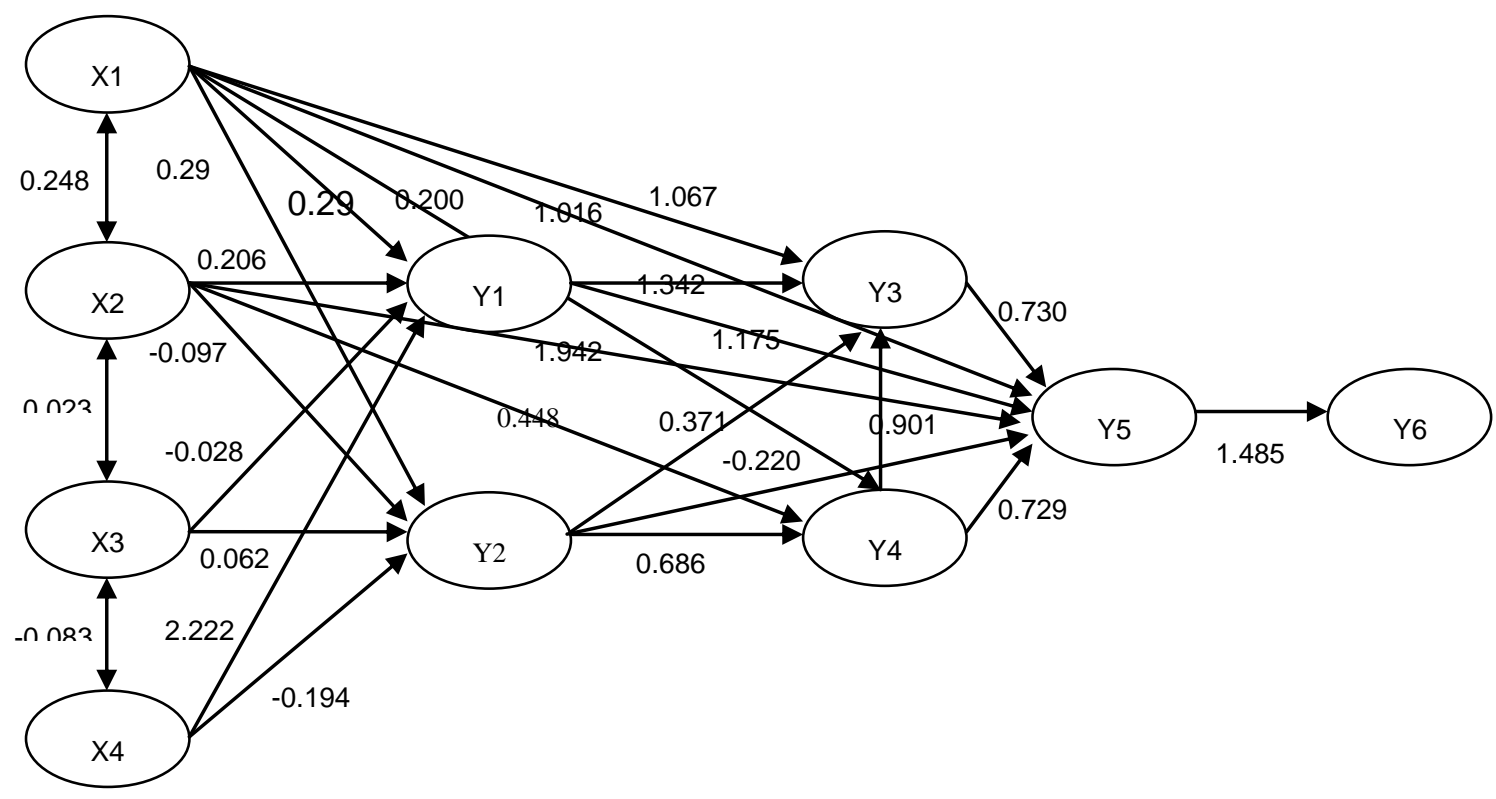

Keterangan:

$\mathrm{X} 1=$ Kondisi sosial ekonomi, $\mathrm{X} 2=$ Modal sosial, $\mathrm{X} 3$ = Lingkungan fisik, $\mathrm{X} 4$ = Lingkungan megapolitan. Y1 = Ketersediaan sarana dan prasarana, Y2 = Kemampuan akses informasi, Y3= Teknologi, Y4 = Tingkat motivasi, Y5 = Keberdayaan, Y6= Ketahanan Pangan .

\section{Gambar 3. Model Pemberdayaan Petani Menuju Ketahanan Pangan Keluarga di Daerah Kota}

Dari Gambar 3 terlihat bahwa variabel lingkungan megapolitan merupakan faktor determinan terhadap ketahanan pangan melalui ketersediaan sarana produksi dan permodalan, serta tingkat keberdayaan petani terhadap ketahanan pangan dengan pengaruh total (total effect) sebesar $B=4.428157$ lebih tinggi bila dibandingkan dengan jalur lainnya. Hal ini menunjukkan bahwa peningkatan keberdayaan petani di desa kota dapat dimulai dengan pengembangan dan penguatan lingkungan megapolitan yaitu pengembangan kerjasama bidang pemasaran antara kelompok tani dengan kelembagaan tani antar propinsi/ kabupaten/ kota, kemudian penguatan sarana produksi dan permodalan.

\section{Model Pemberdayaan Petani pada Kondisi Gabungan Desa-Kota}

Model pemberdayaan petani pada wilayah gabungan desa kota ternyata hampir sama dengan model pemberdayaan di wilayah perkotaan, dimana lingkungan megapolitan muncul sebagai faktor yang berpengaruh kuat terhadap keberdayaan petani (Gambar 4). 


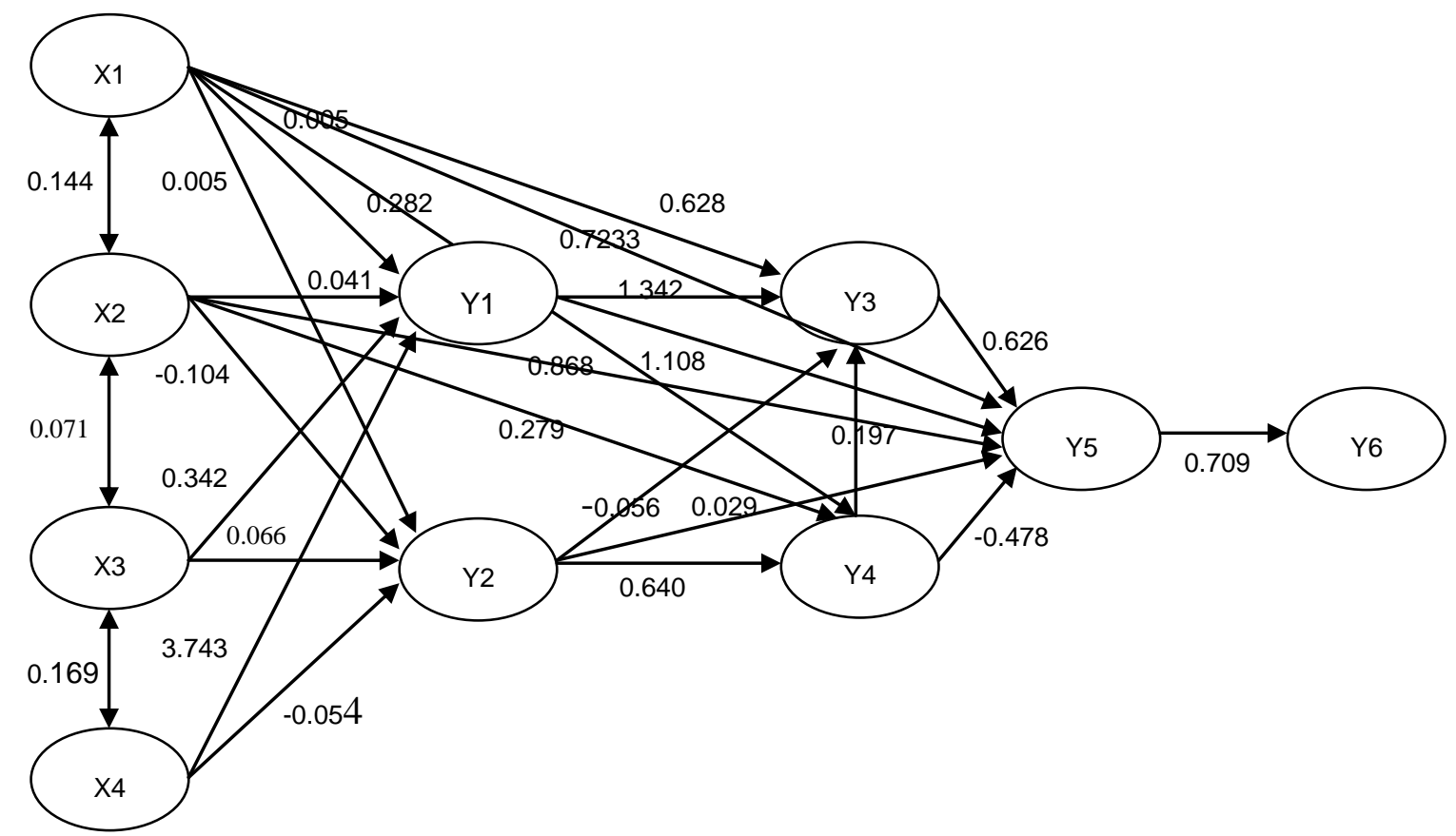

Keterangan:

$\mathrm{X} 1$ = Kondisi sosial ekonomi, $\mathrm{X} 2=$ Modal sosial, $\mathrm{X} 3$ = Lingkungan fisik, $\mathrm{X} 4$ = Lingkungan megapolitan, $\mathrm{Y} 1=$ Ketersediaan sarana dan prasarana, $\mathrm{Y} 2=$ Kemampuan akses informasi, $\mathrm{Y} 3=$ Teknologi, Y4 = Tingkat motivasi, Y5 = Keberdayaan, Y6 = Ketahanan Pangan

\section{Gambar 4. Model Pemberdayaan Petani Menuju Ketahanan Pangan Keluarga (Gabungan Pedesaan dan Kota)}

Dari Gambar 4 terlihat bahwa variabel lingkungan megapolitan melalui ketersediaan sarana produksi dan permodalan, serta tingkat keberdayaan petani merupakan jalur yang paling tinggi pengaruhnya terhadap ketahanan pangan dengan pengaruh total (total effect) sebesar $B=2.94040$ lebih tinggi bila dibandingkan dengan jalur lainnya.

\section{KESIMPULAN DAN SARAN}

\section{Kesimpulan}

Sebagian besar petani merupakan yang tahan pangan (57.9\%), sedangkan $42.1 \%$ lainnya merupakan keluarga yang rawan pangan. Namun bila dilihat dari tingkat keberdayaannya dalam usaha tani, maka sebagian besar petani (52.6\%) masuk dalam kategori tingkat keberdayaan rendah.

Model peningkatan keberdayaan keluarga petani untuk daerah pedesaan dimulai dengan penguatan lingkungan sosial berupa penguatan norma masyarakat, interaksi dalam masyarakat, dukungan keluarga dan tokoh. Sedangkan peningkatan keberdayaan petani di perkotaan dapat dimulai dengan pengembangan dan penguatan lingkungan megapolitan yaitu pengembangan kerjasama bidang pemasaran antara kelompok tani dengan kelembagaan tani antar propinsi/ kabupaten/kota, kemudian penguatan sarana produksi dan permodalan. Demikian pula peningkatan keberdayaan petani di desa kota dapat dimulai dengan pengembangan dan penguatan lingkungan megapolitan yaitu pengembangan kerjasama bidang pemasaran antara kelompok tani dengan kelembagaan tani antar propinsi/kabupaten/kota, kemudian penguatan sarana produksi dan permodalan.

\section{Saran}

Melihat sebagian besar petani dalam kondisi keberdayaan yang rendah, maka perlu upaya yang serius untuk menanganinya. Pemberdayaan petani untuk baik daerah pedesaan maupun perkotaan selain tetap mempertahankan modal sosial yang tinggi, juga sebaiknya menguatkan kerjasama kelembagaan bisnis, pelayanan informasi serta pemasaran, disamping penguatan modal fisik dan sumberdaya manusia. 


\section{DAFTAR PUSTAKA}

Alimoeso S. 2008. Ketahanan pangan nasional: Antara harapan dan kenyataan. Makalah disampaikan pada Pameran Agrinex di Jakarta, Maret 2008.

[FAO] Food and Agriculture Organisation. 2003. Proceedings, Measurement and Assessment of Food Devrivation and Undernutrition. Internastional Scientific Symposium. Rome, 26-28 Juni 2002.

Hakim L. 2007. Pemberdayaan Petani Sayuran: Kasus Petani Sayuran di Sulawesi Selatan. Disertasi. Sekolah Pascasarjana IPB. Bogor.

Hubeis AVS. 2000. Tantangan dan Prospek Teknologi Informasi dan Komunikasi dalam Otonomi Daerah. Dalam Prosiding Seminar Nasional. Kerjasama Program Studi Ilmu Penyuluhan Pembangunan PPS -IPB Bogor dengan Perhimpunan Ahli Penyuluhan Pembangunan Indonesia (PAPPI). Diedit oleh: R. Pambudy \& Andriono K. Adhi. Pustaka Wirausaha Muda. Bogor.

Kenny DA. 1979. Correlation an Causality. Wiley. New York.

Nainggolan K. 2008. Kebijakan Ketahanan Pangan dan Strategi Pengembangan Daerah. Makalah Seminar Pangan dan Sektor Agribisnis. Kadin Indonesia. Jakarta, 22 Januari 2008.
Roosganda E. 2007. Fenomena Sosiologis Metamorphosis Petani: Ke Arah Keberpihakan Pada Masyarakat Petani di Pedesaan Yang Terpinggirkan Terkait Konsep Ekonomi Kerakyatan. Forum Penelitian Agro Ekonomi. Volume 25 No. 1, Juli 2007:29 - 42.

Syahra R, Hanim MS, Kusumawardhani DTP, \& Manan MA. 2000. Anomie dan Modal Sosial: Memahami Krisis Multi Dimensional. Puslitbang Kemasyarakatan dan Kebudayaan LIPI. Jakarta.

Sumawinata S. 2004. Politik Ekonomi Kerakyatan. Gramedia. Jakarta.

Sumodiningrat, G. 1999. Pemberdayaan Masyarakat dan Jaring Pengaman Sosial. Gramedia. Jakarta.

Tanziha I. 2006. Peningkatan validitas Instrument Kelaparan. Departemen Gizi Masyarakat. Fakultas Ekologi Manusia. IPB.

Thoha M. 2002. Perilaku Organisasi; Konsep Dasar dan Aplikasinya. Manajemen PT. Raja Grafindo Persada. Jakarta.

Yamin S \& Kurniawan H. 2009. SPSS Complete : Teknik Analisis Statistik Terlengkap dengan Software SPSS. Salemba Infotek. Jakarta. 